A

\title{
Rевевсн Автіск: Impact of cluster frontline demonstrations on red gram in Davanagere district
}

\author{
J. Raghuraja, T.N. Devaraja, H.M. Sannagoudra and B.O. Mallikarjuna
}

Article Chronicle: Received :

15.03.2020;

Revised :

09.04.2020;

Accepted :

17.04.2020

KEY WoRDS:

BRG-5 variety, Red

gram, Cluster frontline demonstrations, Seed, Direct selling, Horizontal spread, Vertical spread, Technology gap, Extension gap, Technology index

SUMMARY : In order to introduce suitable intercrop in maize, ICAR-Taralabalu Krishi Vigyan Kendra, Davanagere has taken up cluster frontline demonstrations on integrated crop management in red gram and introduced BRG-5 variety. The demonstrations were conducted in 2 clusters namely, Santebennur and Devarahalli during 2017-18 and 2018-19, respectively covering 100 farmers (50/year). The results reveals that the increase in yield was found to be 27.13 per cent and 27.8 per cent during 2017-18 and 2018-19, respectively. The technology index was 20.66 per cent and 20.93 per cent. During 2018-19, FLD farmers sold $31.4 \mathrm{q}$ as seeds to 280 farmers. In 2019-20, 26 FLD farmers sold $26.8 \mathrm{q}$ as seeds to 169 farmers. The seed procurement agency sold 20.6 q. and 74.5q. during 2018-19 and 2019-20, respectively, including through Raith Sampark Kendras. The data on vertical spread of technology reveals that 68 per cent and 52 per cent FLD farmers continued with BRG-5 variety during 2018-19 and 2019-20, respectively. Main reasons for non-adoption of BRG-5 red gram variety during 2019-20 are red gram is not profitable as maize (79.1\%), lack of rainfall during June and July $(45.83 \%)$, difficulty in use of weedicide maize (33.33\%) and wilt problem (20.83\%).

How to cite this article : Raghuraja, J., Davaraja, T.N., Sannagoudra, H.M. and Mallikarjuna, B.O. (2020). Impact of cluster frontline demonstrations on red gram in Davanagere district. Agric. Update, 15(1 and 2): 75-78; DOI : 10.15740/HAS/AU/15.1and2/75-78. Copyright@ 2020: Hind Agri-Horticultural Society. 